\title{
PAST HUMAN IMPACT AND POLLUTANT LOADING RECONSTRUCTION IN LAKE ENGURE AS A TOOL FOR LAKE BASIN MANAGEMENT
}

\author{
Māris Kḷaviṇš\# \\ Faculty of Geography and Earth Sciences, University of Latvia, Raina bulv.19, LV-1586, Rīga, LATVIA \\ \# Corresponding author
}

Contributed by Māris Kḷaviṇ̌̌

\begin{abstract}
Environmental pollution of lakes and rivers is considered as one of the most important environmental problems. Analysis of nutrient and trace element accumulation in sedimentary phases of lakes can reflect the overall regional pollution level, and the observed accumulation patterns of pollutants in sediment profiles can be used to reconstruct the history of anthropogenic impacts. As pollutants in sediments are associated with other substances, it is important not only to study total concentrations of pollutants, but also their speciation forms. The aim of this study was to describe phosphorus (including speciation forms) and trace element concentrations in sediment profiles of Lake Engure and to evaluate human impact on organic matter accumulation and properties in lake sediments. The concentrations of the studied elements in sediments of Lake Engure are at background levels, which is clearly evident when compared with metal concentrations in lake sediments in West European countries. The analysis of element concentration changes in sedimentary profiles provided information about trends in recent accumulation (within the last 100 years) and on the balance between natural and human-induced accumulation processes. Analysis of nutrient concentrations in sediments aided in identifying background values as targets for lake management activities.
\end{abstract}

Key words: lake sediments, nutrients, trace and major elements, organic matter.

\section{INTRODUCTION}

Human activities have led to accumulation of pollutants and nutrients in lakes, thus supporting increased primary productivity in lakes, structural changes in food webs and deterioration of quality of waterbodies (Wetzel 2001). Lake sediments act as a sink of pollutants, and their studies can provide valuable information about lake development and can be used to study long-term, natural, human and climate impacts in lake basins (Dearing et al., 2008). Especially vulnerable in respect to human impacts are shallow coastal lakes (Saunders et al., 2008).

Lake Engure is the largest lake of the western coastal area of the Gulf of Riga. It developed after retreat of the Baltic Ice Lake. Nowadays, a $1.5 \mathrm{~km}$ to $2.5-3 \mathrm{~km}$ wide belt of land separates Lake Engure from the Gulf of Rìga. The lake is shallow, with uneven bottom relief covered by sand, silty clay, silt with organic matter and gyttja. The lake was strongly influenced by excavation of the Merrsrags Canal (in 1842), which caused an abrupt lake water level decrease by 1.5 to $2 \mathrm{~m}$ and start of intensive agricultural activities in the former lake littoral zone as well as fen peat formation (Eberhards and Saltupe, 2000).
Lake Engure is surrounded by forests (Vikssne, 1997). Sources of human impact are transboundary air pollution as well as pollutant loading via the main tributaries (rivers Dzedrupe, Dursupe, Jurğupe, Kalnupe, and Melnupe). Analysis of sedimentary records of major and trace elements (Renberg et al., 2001; Lepane et al., 2010) and phosphorus and organic substances (Marchetto and Musazzi, 2001; Rasanen et al., 2007) can be used as a tool to study historical changes of lake development ). Sediments in lakes can act as nutrient sinks or sources and phosphorous biogeochemistry thus often is considered as a major factor affecting lake trophic status and quality of waters.

The aim of this study was to determine phosphorus (including speciation forms) and trace element concentrations in sediment profiles of Lake Engure and to evaluate human impact on the organic matter accumulation and properties in lake sediments.

\section{MATERIALS AND METHODS}

The sediment sampling sites in Lake Engure used within this study are shown in Figure 1 and it has been done for Lake Engure in three sites: 


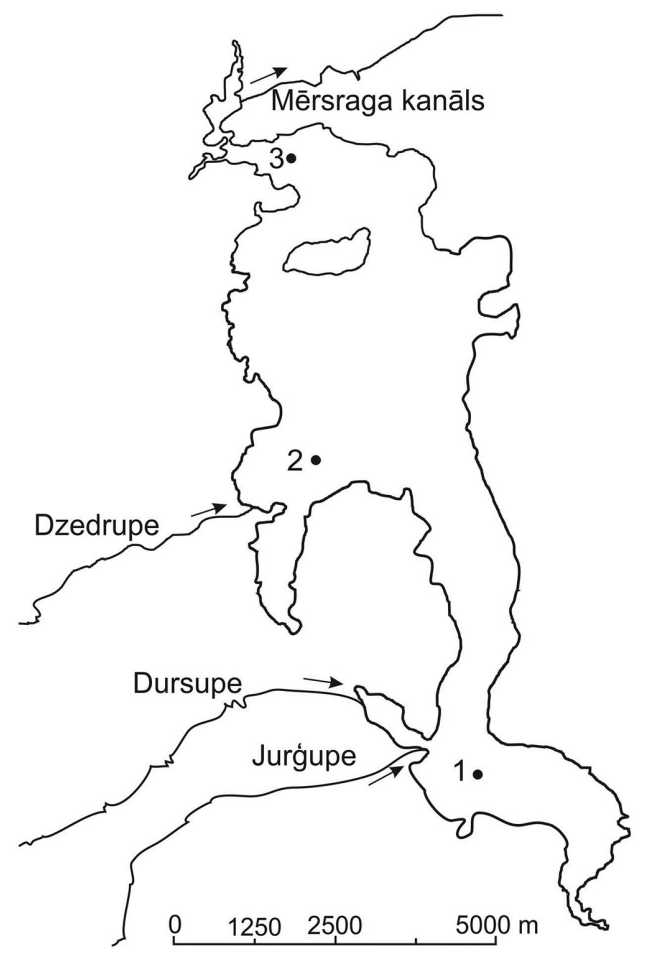

Fig. 1. Location of the study area and lake sediment sampling sites.

1) lake sediments at the southern part of the lake (core No. 1$),\left(57^{\circ} 12^{\prime} 520 ; 23^{\circ} 08^{\prime} 868\right)$;

2) in the central part of the lake (core No. 2) $\left(57^{\circ} 26^{\prime} 256\right.$; $\left.23^{\mathrm{o}} 10^{\prime} 584\right)$.

3 ) in the northern part of the lake (core No. 3). $\left(57^{\circ} 17^{\prime} 271\right.$; $23^{\circ} 15^{\prime} 912$ );

Sediment dating of the upper $35 \mathrm{~cm}$ layers was made using ${ }^{210} \mathrm{~Pb}$ analysis by known methods (Schönhofer and Wallner, 2001).

The surface sediment layer were sampled by Ekman drag. Additionally, sediment cores were taken from three different parts of the Lake Engure using a gravity corer with Plexiglas tube of diameter of $35 \mathrm{~mm}$. Sediment cores were sliced into $1 \mathrm{~cm}$ thick layers. The dried and sieved $(<100$ $\mu \mathrm{m})$ samples $(\sim 1 \mathrm{~g})$ were digested with $50 \% \mathrm{HNO}_{3}$ and $30 \% \mathrm{H}_{2} \mathrm{O}_{2}$ on a hot plate at $70 \pm 5{ }^{\circ} \mathrm{C}$ (Csuros and Csuros, 2002). Content of organic matter and carbonates in sediments was determined by loss-on-ignition (LOI) analysis as described in (Dean, 1974; Bengtsson and Enell, 1986; Heiri et al., 2001). Metal concentrations were measured by flame atomic absorption (Perkin Elmer 503). The reliability and accuracy of analytical results were checked using blank and reference (SLRSS-2 river water, BCSS- coastal marine sediments; Analytical Chemistry Standards NRC, Canada) samples. The results from the analysis of SRM were all within the 95\% confidence level of the SRMs.

Total phosphorus $\mathrm{P}$ in sediments was determined by ashing samples at $550{ }^{\circ} \mathrm{C}$ for $3 \mathrm{~h}$ and subsequent extraction with $0.5 \mathrm{M} \mathrm{HCl}$. Inorganic phosphorus was analyzed in extracts by the ascorbic acid method (Anonymous, 2005).
Table 1

SEQUENTIAL EXTRACTION PROCEDURE OF PHOSPHORUS SPECIATION FORMS (modified method after Psenner et al., 1984)

\begin{tabular}{|c|c|c|c|}
\hline Step & Reagents & $\begin{array}{c}\text { Extraction } \\
\text { time }\end{array}$ & Fractions extracted \\
\hline I & $1 \mathrm{M} \mathrm{NH}_{4} \mathrm{Cl}$ & $4 \mathrm{~h}$ & $\begin{array}{l}\mathrm{NH}_{4} \mathrm{Cl}-\mathrm{P} \text { - pore water } \mathrm{P} \text {, loosely ad- } \\
\text { sorbed } \mathrm{P}\end{array}$ \\
\hline II & $\begin{array}{c}0.11 \mathrm{M} \mathrm{NaHCO}_{3}+ \\
0.11 \mathrm{M} \mathrm{Na}_{2} \mathrm{~S}_{2} \mathrm{O}_{4}\end{array}$ & $1 \mathrm{~h}$ & $\begin{array}{l}\mathrm{BD}-\mathrm{P}-\text { redox sensitive } \mathrm{P} \text { (P associ- } \\
\text { ated with } \mathrm{Fe} \text { and } \mathrm{Mn} \text { hydroxides) }\end{array}$ \\
\hline III & $1 \mathrm{M} \mathrm{NaOH}$ & $16 \mathrm{~h}$ & $\begin{array}{l}\mathrm{NaOH}-\mathrm{P}-\mathrm{P} \text { associated with metal } \\
(\mathrm{Fe}, \mathrm{Al}) \text { oxides; hydrolysed organic } \mathrm{P}\end{array}$ \\
\hline IV & $0.5 \mathrm{M} \mathrm{HCl}$ & $17 \mathrm{~h}$ & $\begin{array}{l}\mathrm{HCl}-\mathrm{P} \text { - carbonate-bound and apatite } \\
\mathrm{P}\end{array}$ \\
\hline
\end{tabular}

Sequential extraction of phosphorus speciation forms was carried out following the modified method of (Psenner et al., 1984) (Table 1).

\section{RESULTS}

Lake Engure belongs to the transitional-accumulative type of lakes. Thickness of the sediment layer with organic matter, which mainly consisted of silty or clayey gyttja, varied from $1-2 \mathrm{~m}$ in the northern part of the lake to $3 \mathrm{~m}$ in the northern part of the lake, due to the uneven relief of the lake depression bottom, as well as complicated hydrological regime of the lake, including water level changes caused by both natural and anthropogenic conditions.

Composition of the studied sediments is presented in Table 2. LOI analysis revealed that the fraction of mineral matter was dominating (49.8-93.6\%) in sediments of lakes in Latvia. Content of organic matter (OM) was 4.3-46.2\%. Carbonate matter $(\mathrm{CM})$ content varied from $1.2-10.2 \%$.

The highest concentration of the studied metals was observed for Ca (6060-61 $665 \mathrm{mg} / \mathrm{kg}$ d.w.) and Fe (7900-38 $980 \mathrm{mg} / \mathrm{kg}$ d.w.). $\mathrm{Mg}$ and $\mathrm{K}$ were also found in high concentrations $3600-1100 \mathrm{mg} / \mathrm{kg}$ d.w. and $980-4600 \mathrm{mg} / \mathrm{kg}$ d.w., respectively, as well as $\mathrm{Mn} 126-2150 \mathrm{mg} / \mathrm{kg}$ d.w. (not shown in the table). The order of heavy metals according to their concentration was $\mathrm{Zn}>\mathrm{Pb} \geq \mathrm{Cr}>\mathrm{Ni}>\mathrm{Cu}>\mathrm{Cd}$. Concentrations of total phosphorus in lakes of Latvia varied between $340-2360 \mathrm{mg} / \mathrm{kg}$ d.w. (Table 2); the concentration in sediments of Lake Engure was relatively low, but still higher than in lakes with low human impact.

The character of the sedimentation processes can be examined using lake sediment dating by ${ }^{210} \mathrm{~Pb}$ activity and a depth-age model (Fig. 2) that takes into account sediment compaction. Of course, differences in sedimentation processes in the lake water body should be considered. The suggested sediment age-depth models can be used to study changes in sediment composition caused by human impact.

Loss-on-ignition (LOI) analysis of sediment samples (Fig. 3) indicates significant changes of sedimentation conditions with time: randomly increasing organic matter concentration until the uppermost sediment layers. This indicates intensive, but stable production of organic substances and 
COMPOSITION OF THE UPPER LAKE SEDIMENTS $(0-10 \mathrm{~cm})$ IN LAKES OF LATVIA

\begin{tabular}{|c|c|c|c|c|c|c|c|c|c|c|}
\hline Lake & $\begin{array}{c}\text { Organic } \\
\text { matter, \% }\end{array}$ & $\mathrm{P}_{\text {tot }}, \mathrm{mg} / \mathrm{kg}$ & $\mathrm{Cr}, \mathrm{mg} / \mathrm{kg}$ & $\mathrm{Mn}, \mathrm{mg} / \mathrm{kg}$ & $\mathrm{Co}, \mathrm{mg} / \mathrm{kg}$ & $\mathrm{Ni}, \mathrm{mg} / \mathrm{kg}$ & $\mathrm{Cu}, \mathrm{mg} / \mathrm{kg}$ & $\mathrm{Zn}, \mathrm{mg} / \mathrm{kg}$ & $\mathrm{Cd}, \mathrm{mg} / \mathrm{kg}$ & $\mathrm{Pb}, \mathrm{mg} / \mathrm{kg}$ \\
\hline Alauksts & 38.5 & 807.5 & 32.8 & 261 & 9.6 & 23.4 & 22.0 & 122 & 1.02 & 61.59 \\
\hline Dagdas & 23.7 & 2361.2 & 23.4 & 1733 & 6.4 & 16.0 & 16.9 & 68 & 0.31 & 20.91 \\
\hline Drīdzis & 17.2 & 340.6 & 7.7 & 49 & 1.4 & 4.1 & 2.7 & 16 & 0.09 & 3.06 \\
\hline Ežezers & 29.8 & 601.4 & 33.9 & 399 & 9.3 & 24.0 & 24.5 & 116 & 0.58 & 35.25 \\
\hline Laucesas & 18.8 & 1029.9 & 27.7 & 481 & 7.1 & 19.1 & 18.6 & 79 & 0.26 & 18.07 \\
\hline Lejas & 12.5 & 766.9 & 27.4 & 288 & 9.7 & 19.9 & 19.0 & 76 & 0.06 & 15.44 \\
\hline Nirza & 19.8 & 763.6 & 25.2 & 384 & 9.8 & 18.5 & 22.8 & 85 & 0.40 & 24.86 \\
\hline Rāzna & 18.0 & 2178.7 & 0.9 & 93 & 0.2 & 0.5 & 0.6 & 3 & 0.13 & 2.04 \\
\hline Sīvers & 19.0 & 648.7 & 47.1 & 410 & 11.8 & 31.5 & 23.5 & 81 & 0.08 & 22.56 \\
\hline Stirnu & 23.3 & 2324.0 & 25.8 & 2153 & 7.7 & 19.6 & 23.4 & 78 & 0.51 & 27.50 \\
\hline Sventes & 17.9 & 630.1 & 42.3 & 367 & 9.3 & 28.9 & 18.4 & 78 & 0.33 & 28.89 \\
\hline Engures* & 24.8 & 450.3 & 13.7 & 293 & 3.5 & 10.2 & 16.4 & 64 & 0.42 & 22.10 \\
\hline
\end{tabular}

* - average for all sampling stations

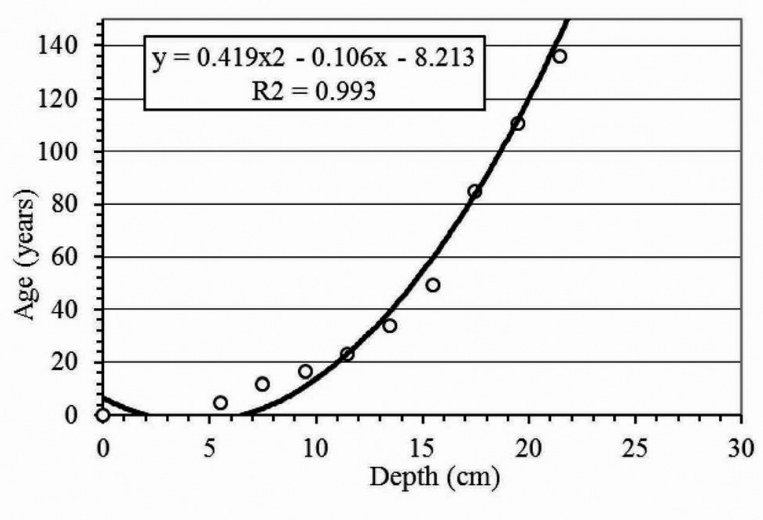

Fig. 2. Lake Engure sediment depth-age model, taking into account sediment compaction (sampling station 2, sediment mass accumulation rate of $0.03 \mathrm{~g} / \mathrm{cm}^{2} /$ year was constant based on model assumption, linear sedimentation rate was $0.15 \mathrm{~cm} /$ year for top most slice and $0.028 \mathrm{~cm} /$ year for lower slices.) $\bigcirc$ - measured sediment age: — - depth-age model calculations. their sedimentation, with less intensive organic matter sedimentation before 1960. In sediments from the northern part of the lake, organic matter concentration increased only in the last years. In the southern part of the lake, organic matter sedimentation conditions during the last decades have been relatively stable. Carbonate sedimentation conditions have been stable in the central part of the lake, but have significantly increased both in the southern and northern part during the last decades.

An essential element influencing development of biota in waterbodies is phosphorous (Fig. 4). Of special importance is biologically available phosphorus, which promotes eutrophication and growth of macrophytes in lake. Phosphorous concentrations in the lake central and northern parts slightly increased starting from the middle of $20^{\text {th }}$ century, but during the last decades phosphorus accumulation in these basins of the lake decreased. However, in the southern part of the lake, which represents a significant part

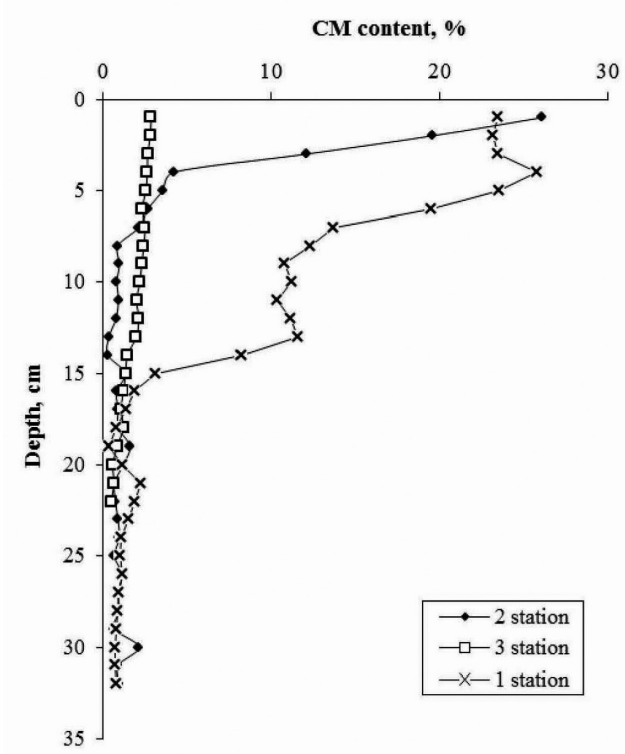

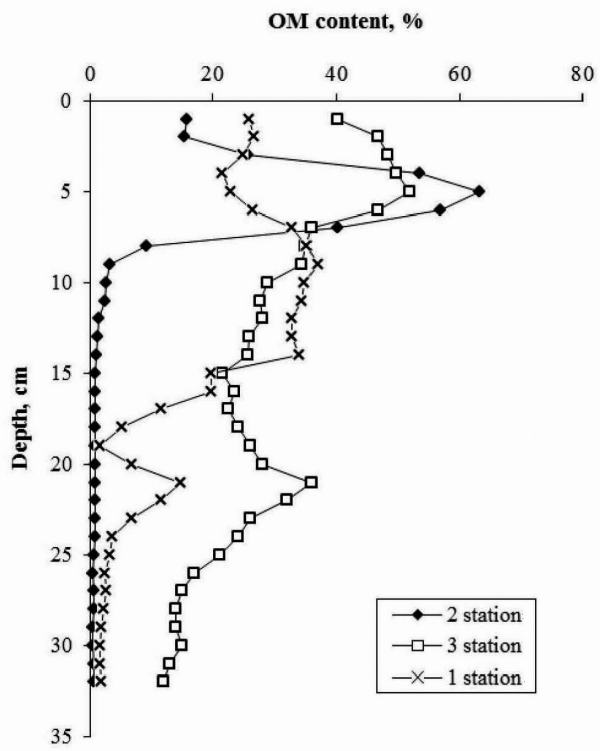

Fig. 3. Concentration of organic matter $(\mathrm{OM})$ and carbonates $(\mathrm{CM})$ in the Lake Engures sediment profiles (sampling sites as in Fig. 1). 


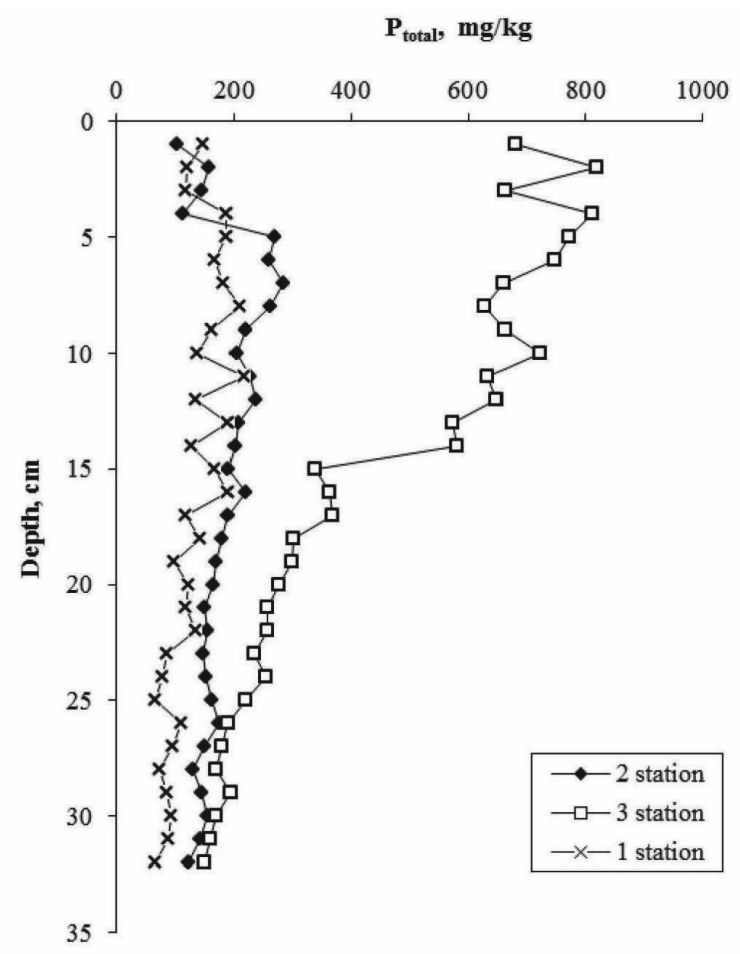

Fig. 4. Concentration of total phosphorous in Lake Engure sediment profiles (sampling sites as in Fig. 1).

of the waterbody, the concentrations during last 30-40 years have significantly increased, indicating major accumulation of phosphorus.

Phosphorus as a major element limiting eutrophication of waterbodies can exist in so-called speciation forms (bound to different organic or inorganic substances with much differing biological availability). These forms can be determined using a selective extraction method (Table 1, Psenner et al., 1984). Phosphorus speciation forms were determined in sediments of four lakes in Latgale with different pollution loading and in Lake Engure sediments (Figs. 5, 6). Concentrations of the easily extractable phosphorus speciation form $\mathrm{NH}_{4} \mathrm{Cl}-\mathrm{P}$ were in the range $0.05-50.21 \mathrm{mg} / \mathrm{kg}$ d.w., with the lowest concentration in Lake Drïdzis and the highest in the uppermost layers in Lake Engure. The easily extractable phosphorus speciation form $\mathrm{NH}_{4} \mathrm{Cl}-\mathrm{P}$ raises the most concern regarding ability to support eutrophication and, during turbulence, to form particulate matter. Concentration of $\mathrm{NH}_{4} \mathrm{Cl}-\mathrm{P}$ in composite sediment samples in lakes in Latgale was less than $0.35 \%$ of total phosphorus, campared to $12 \%$ in the uppermost sediment layers in Lake Engure. Concentrations of reducible $\mathrm{P}$ species (BD-P) varied from $3.2-361.3 \mathrm{mg} / \mathrm{kg}$ d.w. (0.9-15.6 \% of total P content). Concentrations of inorganic $\mathrm{P}$ extracted in $\mathrm{NaOH}$ (NaOH-P) ranged from $9.5 \mathrm{mg} / \mathrm{kg}$ to $477 \mathrm{mg} / \mathrm{kg}$, and of $\mathrm{HCl}-\mathrm{P}$ from $81.9 \mathrm{mg} / \mathrm{kg}$ to $894.0 \mathrm{mg} / \mathrm{kg}$.

To identify the human impact dimension on the lake, the major and trace element accumulation character in a full profile of lake sediments was examined (Figs. 4-10). In the sediment profile, patterns of $\mathrm{K}$ and $\mathrm{Na}$ concentration changes had an opposite character, with increasing $\mathrm{Na}$ con-

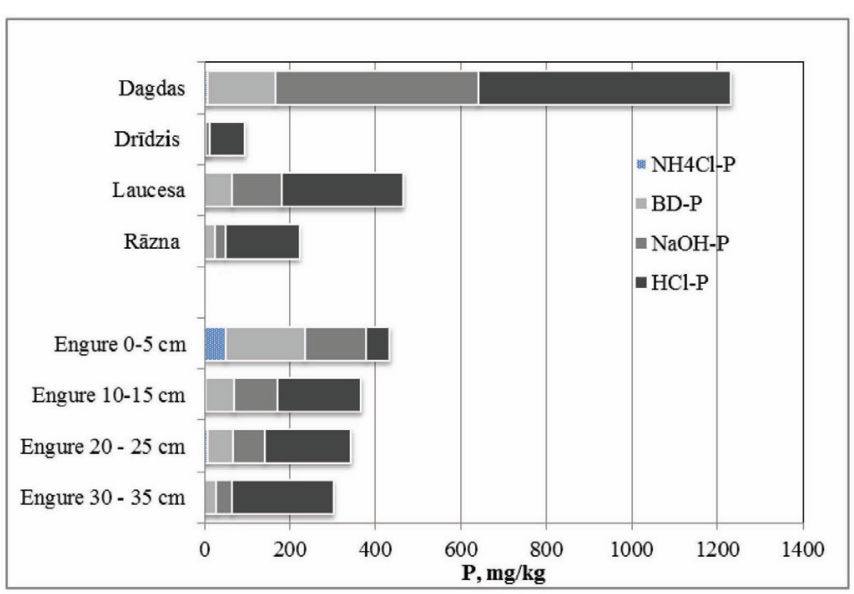

Fig. 5. Phosphorus speciation forms ( $\mathrm{mg} / \mathrm{kg}$ d.w.) in lake sediments.

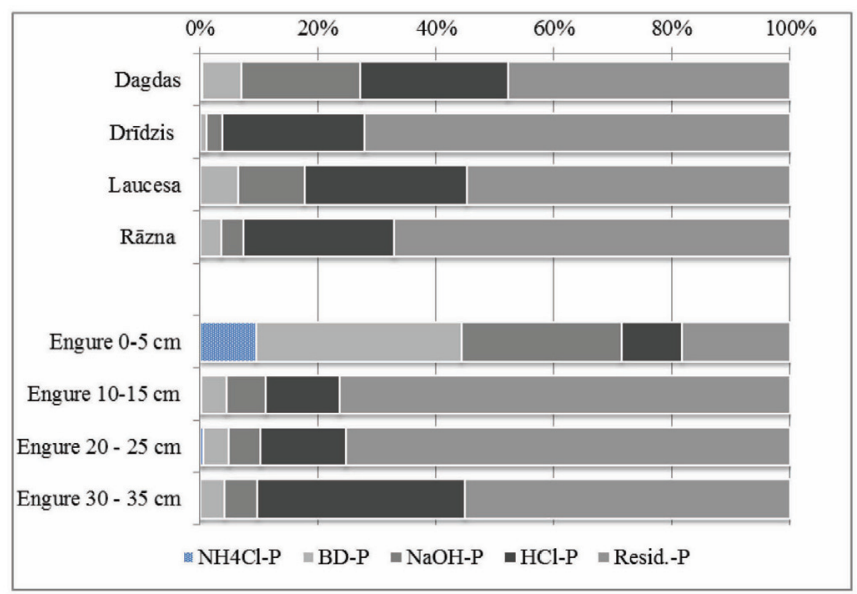

Fig. 6. Distribution of phosphorus speciation forms as a percentage of total phosphorus in lake sediments.

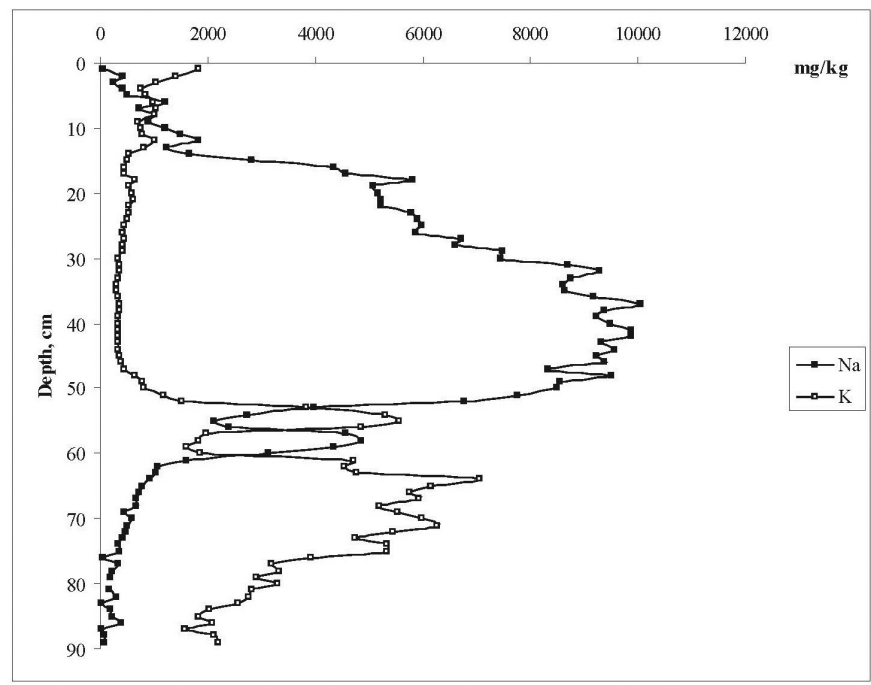

Fig. 7. Na and K concentrations in a profile of Lake Engure sediments (station 2 - central part of the lake).

centration after building of Mērsrags Canal in 1842 caused by inflow of brackish waters from Gulf of Rìga, and decreasing, $\mathrm{K}$ concentration. Historically, $\mathrm{K}$ concentrations have been elevated, probably due to biogenic origin of $\mathrm{K}$ in the aquatic environment. 


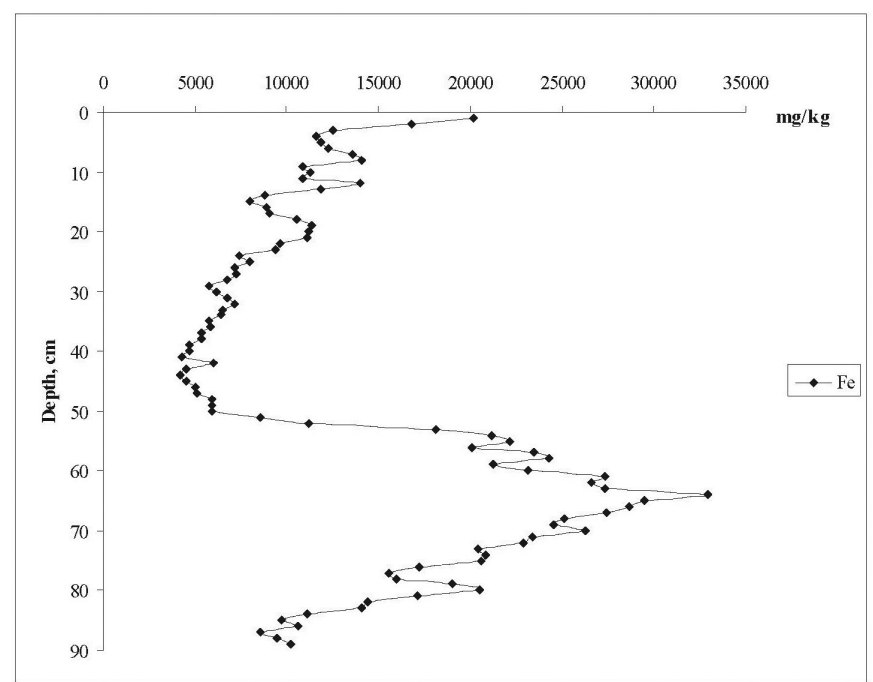

Fig. 8. Fe concentrations in a profile of Lake Engure sediments (station 2 central part of the lake).

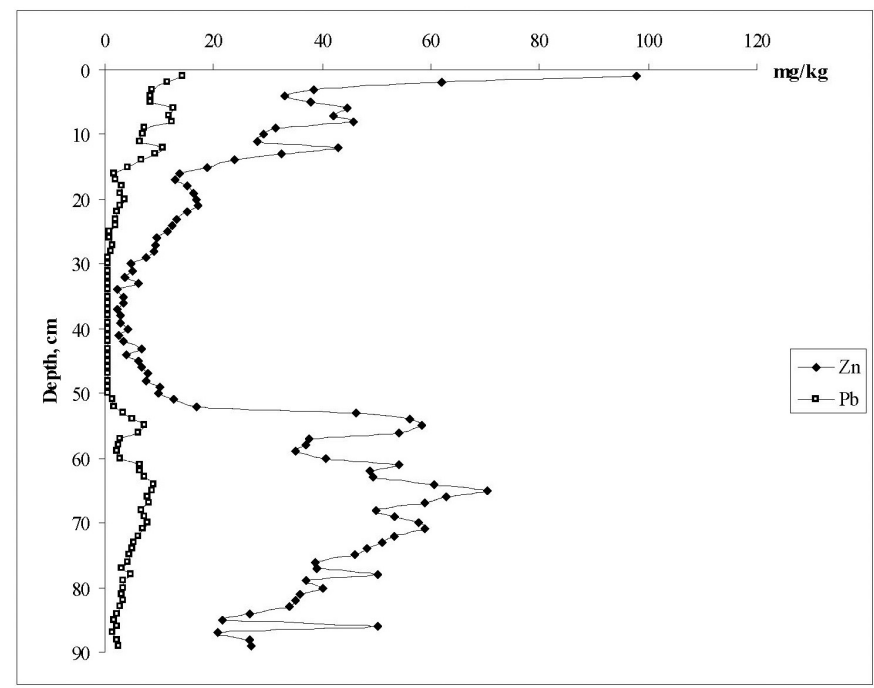

Fig. 9. $\mathrm{Zn}$ and $\mathrm{Pb}$ concentrations in a profile of Lake Engure sediments (station 2 - central part of the lake).

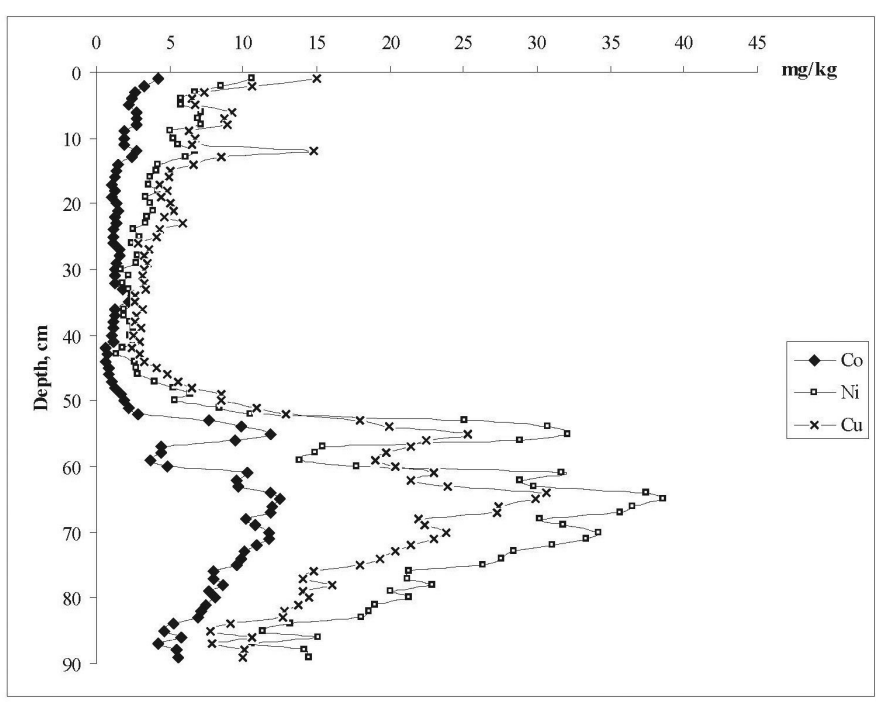

Fig. 10. $\mathrm{Co}, \mathrm{Ni}$ and $\mathrm{Cu}$ concentrations in a profile of Lake Engure sediments (station 2 - central part of the lake).
The pattern of $\mathrm{Fe}$ concentration in Lake Engures sediment profiles indicates major changes in sedimentation caused by building of the Canal connecting lake with the Gulf of Riga in 1842, which resulted in an abrupt decrease of the Fe sedimentation. Changes in the Fe accumulation also can be related to oxygen conditions, as only Fe (III) tends to form stable sedimentary phases. If anoxic events becomes frequent, $\mathrm{Fe}$ (III) can be reduced to soluble forms of $\mathrm{Fe}$ (II) resulting in reduction of iron accumulation. In recent decades, Fe accumulation again has increasing.

Concentrations of trace elements, such as $\mathrm{Pb}, \mathrm{Co}, \mathrm{Ni}, \mathrm{Cu}$, $\mathrm{Zn}$ and others that are associated with human activities, can identify human-caused pollution and changes in the associated loading patterns (Figs. 9, 10).

\section{DISCUSSION}

Sediment accumulation conditions changed during development of the lake. This was indicated by changes in sediment composition, including chemical parameters. Marine water inflow in the Lake through the Mērsrags Canal during autumn and spring periods has major importance. Strong winds promote active water layer mixing and probably, influenced also the very upper soft sediments, as Lake Engure is very shallow. The LOI results also supported the idea that the sediments were mixed. Lake eutrophication and overgrowing processes started approximately 5500 calendar years ago. The lithological composition of sediment profiles indicates that sand sediment fluctuated with sand/organic matter from the bottom part upwards, indicating unstable and changing conditions. According to LOI data, increase in carbonate concnetration in lake sediments occurred during the last 150 years, after creating of the Mērsrags Canal in 1842. These changes were not observed in the southern part of lake, which can be explained by both the large lake basin size and completely different deposit accumulation conditions, which are not strongly connected to the processes in lake itself.

Trace and major element changes in Lake Engure sedimentary profiles were influenced by processes happening during lake development, natural variability of the bedrock in the lake basin, character of land use and human impacts during the last centuries. Sedimentation conditions in the lake, as shown by sediment composition analysis of major constituents (carbonates and organic matter) and nutrients, demonstrates significant heterogeneity in sedimentation conditions in different sub-basins of lake and reduced water flow mobility within the lake water body caused by overgrowth with macrophytes.

Total P concentration in sediments varied greatly (from 141 till $662 \mathrm{mg} / \mathrm{kg}$ ) with the lowest values typical for mesotrophic or slightly eutrophic lakes (Anderson et al., 1993), while the higher values are characteristic of eutrophic lakes (Fig. 4). Co-precipitation of phosphorus with calcite decreases concentrations of dissolved phosphorus in lake waters, as the sediment acts as a phosphorus sink. It is known 
that phosphorus loading and accumulation in waterbodies are dependent on morphological features of lakes ad their catchment. Analysis of phosphorus speciation forms (Figs. 5 , 6) revealed that $\mathrm{HCl}-\mathrm{P}$ comprised $42.1-89.7 \%$ of inorganic $\mathrm{P}$ concentrations, or $23.2-44.0 \%$ of the total sedimentary $\mathrm{P}$ in the studied lake, which corresponds to those found in eutrophic and calcareous lakes. $\mathrm{NaOH}-\mathrm{P}$ was the second most abundant form of inorganic phosphorus, comprising $3.31-38.67 \%$ of inorganic P. This phosphorus form can be considered as potentially bio-available under certain circumstances, e.g., alkaline sediments or prevailing anoxic conditions, as the $\mathrm{NaOH}$ solution extracts not only inorganic phosphorus bound to metal oxides and hydroxides, but can hydrolyze a fraction of organic P. The reducible phosphorus form (BD-P) comprised a slightly smaller part of inorganic P (3.37-28.2\%), and loosely adsorbed P comprised less than $1 \%$ of inorganic P. Regarding high content of organic matter in lake sediments (Table 2), a substantial amount of the residual $\mathrm{P}$ possibly can be organic P. Due to microbial degradation, organic $\mathrm{P}$ is a potential source of dissolved reactive phosphorus to the lake, especially in anoxic conditions, and thus can promote eutrophication (Marchetto and Musazzi, 2001; Rasanen et al., 2007).

Different element groups and their changes in sedimentary profiles demonstrate differing behaviour, largely due to impacts of their sources and processes influencing element accumulation character. $\mathrm{Na}$ and $\mathrm{K}$ concentrations are influenced by their supply with water inflowing from the lake basin, i.e. Na enters with inflow of brackish waters through the Mērsrags Canal. K, as a nutrient, is consumed during the vegetation season by macrophytes. The patterns of $\mathrm{Na}$ and $\mathrm{K}$ concentration in the sediment profile (Fig. 7) have opposite character - increasing Na concentrations while $\mathrm{K}$ concentrations are decreasing.

Relatively low concentrations of $\mathrm{Na}$ in very recent sediments and higher $\mathrm{K}$ concentrations may indicate the importance of decay of higher vegetation litter and release of biogenic K, or low impacts of brackish waters from the Gulf of Riga. A large increase of $\mathrm{Na}$ concentration occurred in sediments at depth $30-50 \mathrm{~cm}$, which roughly corresponds to the period after building of the Mērsrags Canal in 1842. At that time the lake level significantly decreased, and inflow of brackish waters from the Gulf of Rìga started. In deeper sediment layers, K concentration was higher, while Na concentration was lower. Historically, $\mathrm{K}$ concentrations have been elevated, probably due to the biogenic origin of $\mathrm{K}$ in the aquatic environment

Fe concentrations in sedimentary records differ from those of all other studied elements and seemingly are not much affected by anthropogenic pressures (Fig. 8). Elevated concentrations occurred in the deepest sedimentary layers, probably due to carbonate mineral weathering (Psenner et al., 1984). The large variability of $\mathrm{Fe}$ concentrations in recent sedimentary profiles likely indicates high natural variability of sedimentation conditions and weathering of $\mathrm{Fe}$-containing minerals in the lake basin.
Concentrations of trace elements like $\mathrm{Pb}, \mathrm{Co}, \mathrm{Ni}, \mathrm{Cu}$, and $\mathrm{Zn}$ might be due to human caused pollution (Renberg et al., 2001) and indicate changes in pollution loading (Figs. 9, 10). The present study indicates low recent increase of these contaminants in the sediments of Lake Engure.

The results obtained in this study reveal different sedimentation conditions in the lake regarding geological structure, composition and palaeoenvironmental indicators. This study showed that investigation of such large shallow basins as Lake Engure is complicated and provides diverse results, due to different sedimentation conditions and local factors. The effect of geochemical processes is evident, shown by metal concentrations, particulary regarding $\mathrm{Zn}$ and $\mathrm{Pb}$. Vertical distribution of elements in the sedimentary profiles indicates a significant very recent increase (last few decades), However, increasing intensity of sedimentation processes might have occurred during the period 1950-1980, when intensive industrialization of the country occurred. Remarkable changes in the sedimentation processes occurrred after building of the canal connecting Lake with the Gulf of Rìga in 1842, which dramatically changed the intensity of accumulation of many trace elements. These changes occurred when traditional low-intensity agricultural activities in the lake basin were common (the lake basin is relatively sparsely settled and forests and natural meadows dominate). The sedimentary records of elemental composition allowed to follow changes that were anthropogenic and due to natural loading.

In conclusion, the metal concentrations in sediments of Lake Engure are at a background levels. This can be explained with geochemical factors and abundance of sedimentary deposits in the drainage basins, as well as minimal anthropogenic load. However, in several places direct anthropogenic impacts were evident, including point sources and transboundary pollution. Analysis of elemental composition of sediment profiles can provide information about changes of human-induced and natural loading within the lake basin. Studies on lake sediment composition can be used to evaluate long-term natural and anthropogenic impacts on lakes and their catchments, as well as to evaluate potential ecological risks to the lake ecosystems. Concentrations of heavy metals in the studied lakes were at the background level. The order of heavy metals according to their concentration was $\mathrm{Zn}>\mathrm{Pb} \geq \mathrm{Cr}>\mathrm{Ni}>\mathrm{Cu}>\mathrm{Cd}$. Total phosphorus concentrations varied greatly. Phosphorus speciation forms according to their concentrations follow the order: residual $\mathrm{P}>\mathrm{HCl}-\mathrm{P}>\mathrm{NaOH}-\mathrm{P}>\mathrm{BD}-\mathrm{P}>$ $\mathrm{NH}_{4} \mathrm{Cl}-\mathrm{P}$, indicating that the largest part of sedimentary phosphorus is found in its inert form. However, organic phosphorus (part of residual $\mathrm{P}$ and $\mathrm{NaOH}-\mathrm{P}$ ) due to bacterial mineralization can be a potential source of dissolved reactive phosphorus to the lake. A higher proportion of labile phosphorus is characteristic for disturbed lakes.

\section{ACKNOWLEDGEMENTS}

The study was supported by the Latvian Council of Science grant, project "Development of conceptual integrated 
model of socioeconomic biodiversity pressures and drivers and impacts for the long-term socioecological research platform of Latvia”.

\section{REFERENCES}

Anonymous (2005). APHA Standard methods for the examination of water and wastewater. 21st edn. APHA, AWWA, WEF. Baltimore, Maryland. $1368 \mathrm{pp}$.

Anderson, N. J., Rippey, B., Gibson, C. E. (1993). A comparison of sedimentary and diatom-inferred phosphorus profiles: Implications for defining pre-disturbance nutrient conditions. Hydrobiologia, 253, 357-366.

Eberhards, G., Saltupe, B. (2000). Geological history, relief, and deposits of the Lake Engures (Engure) area along the Baltic Sea. Proc. Latv. Acad. Sci. Sect. B, 54, 141-147.

Bengtsson, L., Enell, M. (1986). Chemical analysis. In: Berglund, B. E. (ed.). Handbook of Holocene Palaeoecology and Palaeohydrology. (pp. 268316). Oxford University Press: Oxford.

Csuros, M., Csuros, C. (2002). Environmental Sampling and Analysis for Metals. Boca Raton: CRC Press. 408 pp.

Dean, W. E., Jr. (1974). Determination of carbonate and organic matter in calcareous sediments and sedimentary rocks by loss on ignition: Comparison with other methods. J. Sed. Petrol., 44, 242-248.

Dearing, J. A., Jones, R. T., Shen, J., Yang, X., Boyle, F., Foster, C., Crook, S., Elvin, M. J. D. (2008). Using multiple archives to understand past and present climate-human-environment interactions: The Lake Erhai catchment, Yunnan Province China. J. Paleolimnol., 40 (1), 3-31.
Heiri O., Lotter, A. F., Lemcke, G. (2001). Loss on ignition as a method for estimating organic and carbonate content in sediments: Reproducibility and comparability of results. J. Paleolimnol., 25, 101-110.

Lepane, V., Morriset, M., Viitak, A., Laane, M., Alliksar, T. (2010). Partitioning of metals between operational fractions in the sediment record from Lake Peipsi. Chem. Ecol., 26, 35-48.

Marchetto, A., Musazzi, S. (2001). Comparison between sedimentary and living diatoms in Lago Maggiore (N. Italy): Implications of using transfer functions. J. Limnol., 60 (1), 19-26.

Psenner, R., Pucsko, R., Sager, M. (1984). Die Fraktionierung organischer und anorganischer Phosphorverbindungen von Sedimenten - Versuch einer Definition ökologish wichtiger Fraktionen. Arch. Hydrobiol. Suppl., 70, 111-155.

Rasanen, J., Kentitamies, K., Sandman, O. (2007). Paleolimnological assessment of the impact of logging on small boreal lake. Limnologica, 37, 193-207.

Renberg, I., Bindler, R., Brannvall, M. L. (2001). Using the historical atmospheric lead-deposition record as a chronological marker in sediment deposits in Europe. Holocene, 11 (5), 511-516.

Saunders, K. M., Hodgson, D. A., Harrison, J., McMinn, A. (2008). Palaeoecological tools for improving the management of coastal ecosystems: A case study from Lake King (Gippland Lakes) Australia. J. Paleolimnol., 40 (1), 33-47.

Schönhofer, F., Wallner, G. (2001). Very rapid determination of ${ }^{226} \mathrm{Ra},{ }^{228} \mathrm{Ra}$ and ${ }^{210} \mathrm{~Pb}$ by selective adsorption and liquid scintillation counting. Radioactiv. Radiochem., 12, 33-38.

Vìksne, J. (1997). The Bird Lake Engure. Rīga: Jāṇa sēta. 111 pp.

Wetzel, R. G. (2001). Limnology: Lake and river ecosystems. $3^{\text {rd }}$ ed. New York: Academic Press. 1006 pp.

Received 23 September 2013

\section{ANTROPOGĒNO IETEKMJU UN PIESĀRNOJUMA SLODZES REKONSTRUKCIJA KĀ ENGURES EZERA PĀRVALDĪBAS RISINĀJUMU INSTRUMENTS}

Upju un ezeru piesārṇojums ir uzskatāms par vienu no nozīmīgākajām vides problēmām. Biogēno elementu un toksisko mikroelementu uzkrāšanās nogulumos atspoguḷo piesārnojumu sateces baseinā, bet piesārṇojošo vielu akumulācijas analīze nogulumu profilos ḷauj izsekot cilvēku ietekmes izmain̄ām reğionā. Tomēr, tā kā piesārņojošās vielas ir saistītas ar citām vielām nogulumos, svarīgi ir analizēt ne tikai vielu kopējās koncentrācijas, bet arī to atrašanās formas. Šì pētījuma mērkis ir analizēt fosfora un mikroelementu koncentrācijas un fosfora savienojumu atrašanās formu mainību Engures ezera nogulumu profilos un noteikt antropogēno ietekmju raksturu uz organisko vielu uzkrāšanos un nogulumu īpašībām. Pētīto elementu koncentrācijas Engures ezera nogulumos ir fona koncentrāciju līmenī, īpaši, ja salīdzina ar koncentrācijām Rietumeiropas valstu ūdenstilpju nogulumos. Tomēr elementu koncentrāciju analīze nogulumu profilos ļauj izsekot antropogēnās slodzes intensitātes izmaiņām pēdējo 100 gadu laikā un pamatot nepieciešamās rīcības ezera ilgtspējīgas apsaimniekošanas risinājumu nodrošināšanai. Biogēno elementu koncentrācijas noteikšana ezera nogulumos ḷauj noteikt to fona koncentrāciju līmeņu ezeru kopšanas pasākumu īstenošanai. 